\title{
Between Statements and Actions: A Speech Act Analysis of President Buhari's Media Political Discourses
}

\author{
Sopuruchi Christian Aboh \\ Department of Linguistics, Igbo and Other Nigerian Languages, University of Nigeria, Nsukka, Nigeria \\ Chris Uchenna Agbedo \\ Department of Linguistics, Igbo and Other Nigerian Languages, University of Nigeria, Nsukka, Nigeria
}

\begin{abstract}
The study of Buhari's statements on "jailing of more thieves," "rule of law should be subjected to national interest," and "being fair in federal appointments" seem not to have been approached from speech act perspective. As such, this paper analyses the locutionary acts, illocutionary acts, and the perlocutionary effects of Buhari's statements on the above subject matters. The data were obtained from the online version of Nigerian Dailies. Austin's speech acts theory serves as the theoretical framework for data analysis. The findings of the study reveal that Buhari's statement on "jailing of more thieves" is based on fact that he has already jailed some high-profile Nigerians since he was elected as the President of Nigeria. The findings of the study reveal the locutionary and illocutionary acts of Buhari's statements. The study also shows how Buhari's statements abided by or flouted Austinian felicity conditions. The perlocutionary effects of the statements were also identified.
\end{abstract}

Index Terms - locutionary acts, rule of law, felicity conditions, perlocutionary effects, national interest, Nigeria

\section{BACKGROUND}

Pragmatics has provided approaches for analysing text and talk. Political speeches have received critical attention by pragmatists. For a statement to be tagged political, it must perform a political function and may or may not be uttered by a politician or public office holder (van Dijk, 1997). As such, it behooves politicians to issue press releases and/or make political statements on issues bordering on their constituencies or the polity generally. Buhari, the President of Nigeria, is not left out in this act. Speech act theory has been adopted in analysing different political discourses in Nigeria (cf. Krisagbedo, 2010) but Buhari's statements on "jailing of more thieves," "rule of law should be subjected to national interest," and "being fair in federal appointments" seem not to have been approached using speech acts theory.

On Saturday, the 18th day of August 2018, as Buhari returned from his ten day working vacation in London; he was asked what Nigerians should expect from him as he resumes office. The President replied, "Most Nigerians are expecting me to jail more of the thieves that brought economic problem to the country. I think is being expected of me and I will do it." In another event, Buhari on Sunday, 26th August 2018, in his address delivered at the opening of the 2018 Nigerian Bar Association Annual General Conference in Abuja, made a statement that attracted the reactions of many Nigerians. The President said, "The rule of law must be subject to the supremacy of the nation's security and national interest." He further stated, "Our apex court has had cause to adopt a position on this issue in this regard and it is now a matter of judicial recognition that; where national interest is threatened or there is likelihood of their being threatened, the individual rights of those allegedly responsible must take second place, in favour of the greater good of society." The claim made by the President that the rule of law is subject to national interest generated uproar amongst legal luminaries and citizens of Nigeria. Some refuted the statement (as reported in Asadu, 2018; Egbe, 2018) while Project-2019 (P2019) defended it.

More so, on Monday, the 17th day of September 2018, Buhari received a delegation of Akwa Ibom elders and leaders at the presidential villa. In one of his statements, Buhari opined, "I have taken note of your appreciation of appointments into the Federal Service from your state. I assure you that I shall continue to be fair and equitable in federal appointments to all states of the country." What Buhari meant here is that no state will be sidelined in federal appointments.

Daily, political leaders provide pragmatists with data for scholarly investigation. The above three political discourses of Buhari, obtained from the online version of Nigerian Dailies, will be analysed using speech act theory. The aims of this study are to identify the locutionary acts, illocutionary acts, and perlocutionary effects of these statements and to examine the above speeches of Buhari in order to ascertain whether the speeches are felicitous or infelicitous beginning from when he made the statements and the time of writing this research (October, 2018). In doing this, Austin's (1962) felicity conditions of sincerity, preparatory, executive and fulfilment will be employed. A review of speech acts and felicity conditions will be handled in the next section. 


\section{FRAMEWORK}

Austin's (1962) work, How to Do Things with Words, opened a new area of linguistic research that is rooted in communicative competence and social function order than mere knowledge of linguistic rules as propagated by Chomsky (1957) in his Syntactic Structures. In as much as Austin is credited with the theory of speech acts, it was developed and organised by Searle (1969), a student of Austin. In this regard, Agbedo (2015, p. 306) opines, "While Austin's theory was open ended and Platonic, Searle systemized it, made it formal and Aristotelian, with a set of necessary and sufficient conditions, constitutive of a basic categorization of speech acts."

From the title of Austin's work, it is claimed that individuals perform an action with their utterances, hence the term performatives. Speech acts centres on identifying the intentions of the speaker. Being able to identify this intention requires both linguistic and communicative competence (Ndiribe, 2016) and such act could be "stating a fact, an opinion, confirming or denying something, making a prediction or request, asking a question, issuing an order, giving a permission, a piece of advice, making an offer, promise etc.” (Agbedo, 2010, p. 47). Similarly, Agbedo (2015) notes that speech acts theory aims to do justice to the fact that even though words encode information, people do more things with words than just conveying information and when people convey information, they often convey more than their words encode. Essentially, just as phone and phonemes are units of analysis of phonetics and phonology respectively, morpheme and word for morphology and syntax, speech act is defined as the "basic minimal units of linguistic communication" (Searle, 1969, p. 16).

Austin (1961) draws a line between constatives and performatives. Constative, on the one hand, is the verity or falsity of an utterance while performative, on the other hand, is the action an utterance carries. Austin (1961) further notes that locutionary act is performed alongside illocutionary act because in every locutionary act, instances of promising, warning, committing, ordering, expressing an intention, among others, can be found. In illocutionary act, there is a force with "certain consequential effects upon the feelings, thoughts or actions of the audience, or of the speaker, or of other persons" (Wardhaugh, 2006, p. 285), which Austin calls perlocutionary. "In using a performative utterance, a person is not just saying something but is actually doing something if certain real-world conditions are met" (Wardhaugh, 2006, p. 285).

Nevertheless, the theory highlights three distinct levels of action beyond the utterance itself. These levels as were identified by Austin (1961) include: locutionary act, illocutionary acts, and perlocutionary effect. The locutionary act implies the act of saying something and the forms of the words uttered. On the other hand, illocutionary acts refer to the function of the words i.e. the purpose the speaker has in mind for making such utterances. Perlocutionary effect means the influence the words have on the hearer or decoder. For instance, when someone says "I pronounce you husband and wife", the sentence the person utters is the locutionary act. The force (based on context) which the statement carries to change the order of things is the illocutionary acts whereas the resultant effect of the statement which is changing the single state of the intending couple to a married state is the perlocutionary effect. Utterances have performative verbs such as 'to promise', 'to name', 'to pronounce,' which make the illocutionary force overt. These performative verbs give rise to five categories as highlighted by Austin; verdictives, exercitives, commissives, behabitives, and expositives. Verdictives gives a verdict or an appraisal like 'He is worthy to be promoted. Exercitives, on the other hand, exercises powers by advising, warning, ordering etc. as in 'I declare you a terrorist.' Commissives are characterized by promising, announcing or making someone to execute an action as in 'I hereby declare...' The fourth category, behabitives, comprises issues like blessing, cursing, challenging or apologizing. The last category exposes one's intention (cf. Mey, 2001, Wardhaugh, 2010, Krisagbedo, 2010, Agbedo, 2015).

Later, Searle (1969) reclassified Austin's performatives into; representation (conveys a proposition that is believed to be true); directive (ordering, commanding or requesting); commissives (promising, vowing, pledging); expressives (apologizing, congratulating, appreciating); and declarations (pronouncing, betting, giving a verdict). Mey (2001) criticises the speech act verbs of Austin and Searle by asserting that it is not always the case that the verb 'promise' reflects in commissives. For example, the utterance: "I will be there" is a promise even though the speaker did not say, "I promise to be there." The criticisms Mey (2001) holds against speech acts necessitated his propounding of 'pragmatic acts,' which according to him has to do with action, situated speech, and direct and indirect speech acts.

One recurring feature of speech acts theory is context. Context determines the kind of interpretation that will be given to any utterance. Context is culture-specific. In this regard, Mey (2001, p. 94) notes:

Asking how a particular communicative act functions in a particular society presupposes that we examine the conditions that hold for communication in that society. The language we use, and in particular the speech acts we utter, are entirely dependent on the context of the situation in which such acts are produced (italics ours).

This then implies that there are conditions that are stipulated by the society in analysing language use in different particular contexts. These conditions that are attached to speech acts are what Austin (1962) refers to as the felicity conditions. In other words, any successfully and appropriately performed speech act must have met the felicity conditions of sincerity, preparatory, executive and fulfilment. Any speech act that flouted these conditions, according to Austin (1962), is adjudged infelicitous. These conditions are discussed in section C of data analysis.

Austin's and Searle's contributions to speech acts theory have provided platform for analysing utterances in interactive events. The theory gains required attention and has been applied in different language situations. It awakens 
the consciousness of interactants or interlocutors to know that their words have some actions they perform. As such, they should be conscious of what to say, when to say it, and how to say it (in order to achieve the required result).

In this paper therefore, the selected political discourses of Buhari will be subjected to the three-level analysis of locutionary acts, illocutionary acts and perlocutionary effects. The extent to which the discourses fulfilled the felicity conditions will also be examined.

\section{DATA ANALYSIS}

Here, the selected political discourses of President Buhari will be analysed based on the locutionary acts (the grammar of the language, i.e. the literal meanings of the structures), the illocutionary acts (the intentions of the speaker) and the perlocutionary effects (the effects of the locutionary and illocutionary on the decoders).

\section{A. Locutionary Acts}

Three political discourses of Buhari were selected for this study. These political discourses serve as the locutionary acts. They include:

1. "Most Nigerians are expecting me to jail more of the thieves that brought economic problem to the country. I think is being expected of me and I will do it."

2. "The rule of law must be subject to the supremacy of the nation's security and national interest." He further stated, "Our apex court has had cause to adopt a position on this issue in this regard and it is now a matter of judicial recognition that; where national interest are [sic] threatened or there is likelihood of their being threatened, the individual rights of those allegedly responsible must take second place, in favour of the greater good of society."

3. "I have taken note of your appreciation of appointments into the Federal Service from your state. I assure you that I shall continue to be fair and equitable in federal appointments to all states of the country."

The above utterances are typical political discourses because they were uttered by a politician (the President) and they play political functions. The locutionary acts highlight the intentions of Buhari, which are to continue his fight against corruption by jailing more thieves, his preference of national interest over rule of law, and his eagerness in being fair and equitable in federal appointments that will represent the federal character of Nigeria.

\section{B. Illocutionary Acts of Buhari's Discourses}

Illocutionary acts are what speakers do in line with their locutionary acts. Illocutionary acts are the force speakers apply to their locutionary acts in order to get the desired effects. Few weeks after President Buhari made the statement that he will jail more looters, on the 13th of October 2018, the Presidency placed a ban on 50 high-profile Nigerians who are accused of corruption because their assets are valued at fifty (50) million naira and above. Prior to the statement made by Buhari on jailing more thieves; Buhari, during the 2015 electioneering campaigns, had made the fight against corruption one of his campaign promises and agenda. In his anti-corruption war as the President, Buhari has implemented a number of policies like whistle blowing policy, the Treasury Single Account and the formation of the Presidential Advisory Committee against Corruption. His anti-corruption war made the Archbishop of Canterbury, Justin Welby to say that this particular President (Buhari) is not corrupt and he is trying very hard. The Treasury Single Account (TSA) as implemented in September 2015 demands that all Ministries, Departments and Agencies should remit all incomes, revenues and receipts of the Federal Republic of Nigeria to a single account (Adeolu, 2015). Former President Goodluck Jonathan initiated the TSA policy but lacked the courage to implement it because his administration was not transparent enough but it was fully implemented by Buhari because of his anti-corruption war (Jegede, 2015). In addition, as reported by the acting chairman of the Economic and Financial Crimes Commission (EFCC) in September 2017, about 15\% of Diezani's loot has been recovered. Buhari, in his 2018 Independence Day speech, told Nigerians that the whistle blowing policy has helped Nigeria to recover over 500 billion naira.

Another action that has been performed by Buhari is his statement about jailing more thieves. For him to have said that he will jail more thieves means that he has jailed some thieves in the past. Information Nigeria (2018) on June 17 published a list of top politicians Buhari has sent to jail (although it resides with the Judiciary to send anyone to jail). Some of the persons that have been jailed by Buhari as enumerated by Information Nigeria (2018) are a former governor of Kaduna State, Mukhtar Ramalan Yero who was sent to Kaduna Convict Prison from May 31 to June 6, 2018 because of fraud. More so, a former governor of Plateau State, Jonah Jang spent eight days in Jos prison because of a 12-count charge of diverting 6.3 billion naira alongside a former cashier in the office of the Secretary to the State Government, Yusuf Pam. Another personality that was jailed was a former governor of Adamawa State, Bala James Ngilari. Ngilari was sent to five-year imprisonment in March 2017 for obtaining 25 vehicles worth N167 million naira for his commissioners without due process. A former governor of Taraba State, Jolly Nyame was convicted and sentenced to fourteen-year imprisonment for 1.64-billion-naira fraud. The former National Security Adviser, Colonel Sambo Dasuki has spent many months in detention over allegation of mismanagement of $\$ 2.1$ billion meant for the purchase of arms. Oliseh Metuh, a former spokesman of PDP has been accused by EFCC of receiving N400 million naira from Sambo Dasuki. A list of persons that have been linked with Dasuki mismanagement (Dasukigate) of funds includes: Bello Halliru, Bello Sarkin, Mahmud Aliyu and Attahiru Bafarawa. This highlights some of the actions Buhari 
has taken in his fight against corruption and desire to jail more looters. Some others like the former Chairman of People's Democratic Party (PDP), Adamu Mu'azu and the former Minister of Petroleum, Diezani Alison-Madueke are on self-exile.

In the second discourse used in this study where Buhari purported that the rule of law is subject to national interest, the actions of Buhari after the statement and before it suggest that what Buhari said reflected his position on the subject matter. The rule of law stipulates that no person is above the law. In other words, the laws as enshrined in the constitution must be obeyed by all and sundry.

The failure to obey court orders by the Presidency is another evidence of Buhari's stance on the supremacy of national interest over the rule of law. Olaniyan (2018) concurs that Buhari's flouts the rule of law as demonstrated by "the tendency to pick and choose which court orders it complies with." "This selective application of the rule of law," continues Olaniyan, "implies an agenda of delegitimizing the judiciary and perhaps, inadvertently, rendering it incapable of contributing to the anti-corruption fight." This neglect to court orders by the Presidency is seen once more in the case of Colonel Sambo Dasuki who was granted bail by the judiciary but was illegally detained for over two years.

Buhari's statement, "I shall continue to be fair in my federal appointments" have been backed up with ironical actions. The Federal Character Principle (FCP) in the third schedule of the 1999 constitution as amended states that all governmental institutions should fairly reflect the linguistic, religious, ethnic, and geographic diversity of the country. Section 318 (1) of the 1999 Constitution conceives federal character of Nigeria as "the distinctive desire of the peoples of Nigeria to promote national unity, foster national loyalty and give every citizen of Nigeria a sense of belonging to the nation as expressed in section 14 (3) of the Constitution". Buhari has been heavily criticised for his lopsided appointments where many key public offices are headed by northerners. Buhari made this statement on the 17th of September 2018. Three days before that day, Buhari replaced the acting Director-General of Department of State Service (DSS), Seiyefa, from Bayelsa state with Yusuf Magaji Bichi, from Kano State. After the appointment of Bichi as the new DSS boss, on his visit to Aso villa, the President was reported to have asked Bichi (a person he appointed) if he (Buhari) has met him before. This question posed by the President to Bichi reveals that nepotism overrides competence. Ikhide (2018) reports that the next six qualified individuals to replace Seiyefa are from the southern part of Nigeria. However, Buhari appointed a northerner that retired more than one year ago to head the DSS. Ikhide further remarks that this one-sided appointment occurs in military services where Air Force boss, Inspector General of Police, DG of DSS, Chief of Army Staff, Immigration, Civil Defence and Prison are all from the northern part of Nigeria. This nature of fair federal appointments is what Buhari promises to continue.

\section{Felicity Conditions}

As explained by Austin in his speech acts theory, every illocutionary act has a force that aids it to achieve the desired effects. In order for a speech act to produce the expected force, there are certain conditions, which it must fulfill. These conditions are sincerity, preparatory, executive, and fulfilment. An illocutionary act that fulfills these real world conditions is said to be felicitous whereas illocutionary act that flouts these conditions is said to be infelicitous.

\section{The Sincerity Condition}

The sincerity condition demands that a speaker should believe what he is saying and should show appropriate behaviour when called upon. The sincerity or veracity of Buhari's statement, "I will jail more thieves" cannot be verified because of its futuristic feature. As at the time of writing this research (14-20 October 2018), the attempt Buhari has made to fulfill the promise of jailing more thieves is the banning of fifty (50) high-profile Nigerians from travelling outside Nigeria. This ban is as a result of the accusations against these people over misappropriation of funds, embezzlement or involvement in one corrupt practice or the other. But if one wants to determine the sincerity of Mr. President, the previous efforts of Buhari to jail corrupt politicians can go a long way. The statement, "I shall jail more thieves" implies that there are people Buhari has jailed or detained in the past such as Dasuki, Jonah Jang, Oliseh Metuh among others. Judging based on the previous efforts of the President in jailing kleptomaniacs of Nigeria's resources and the ban of 50 high-profile Nigerians, it can be concluded that Buhari believed what he said. As such, his statement is adjudged to have obeyed the sincerity condition.

On the other hand, the President flouted the sincerity condition in his statement that the rule of law is subject to national interest. One of the key driving principles in a democratic state is the rule of law, which is enshrined in the constitution. In a statement made by the Chief Justice of Nigeria, Walter Onnoghen, he remarked that without the rule of law, the society is doomed. The supremacy of the rule of law over everything is captured in the quote of John Locke, "Where-ever law ends, tyranny begins" and that of Thomas Paine, "In free countries, the law ought to be king, and there ought to be no other." Thomas Sowell in one of his quote opines, "Politics is the art of making your selfish desires seem like the national interest." What Buhari failed to understand is that national interest comprises aligning to a common law that represents equity and fairness under the law. Ironically, five days after Buhari made that comment in front of lawyers and legislators, he said to the visiting German Chancellor, Angel Merkel, that he would always uphold the rule of law in governing the country. Ndukwe (2018) in reaction to the sincerity that could be discerned from Buhari's comments opines, "It is the stark reality of the banality of the president's stance, something he could neither defend nor promote before the civilised world that made him contradict himself before the German Chancellor." As such, Buhari flouted the sincerity condition. 
Buhari's administration has come under heavy criticism in relation to the lopsidedness of his federal appointments based on FCP as stated in Section 318 (1) of the 1999 Constitution (as amended). The statement, "I shall continue to be fair in my federal appointment" suggests that the President has been fair and equitable in his federal appointments and wants to continue in this regard. This statement flouts the sincerity condition because the statement is unbelievable. Facts and figures are against the claim of Buhari that he has been fair in his appointments. Buhari replaced the former acting Director-General of DSS, Seiyefa, a southerner with a northerner, Bichi and also replaced the former Minister of Finance, Kemi Adeosun from South-West with Zainab Ahmed, a northerner. Similarly, these lopsided appointments occur in military services where virtually all the top officials are from the northern part of the country. The speech act of Buhari was not well-performed in relation to the sincerity condition.

\section{Preparatory Condition}

The preparatory condition stipulates that the performer of a speech act must be the appropriate person. The statement of Buhari that he will jail more thieves is inappropriate because it does not constitutionally lie on him to sentence anyone to jail. All adjudicatory functions reside with the judiciary. This statement by the President implies that the judiciary is not independent. The implicature of this statement does not entail recommending to Attorney General of Minister for Justice to take action. Instead, it appears to be a case of total control of the executive and the judiciary. This explains the reason behind the neglect of court orders by the Presidency. In the fight against corruption, the Economic and Financial Crimes Commission (EFCC) is charged with the duty of fishing out corrupt officials. More so, the claim by the President that the rule of law is subject to national interest is inappropriate. In a democratic nation like Nigeria, the President is not the only person to determine what constitutes national interest or not. The event at which the statement was made is also inappropriate. As observed by Ndukwe (2018), it is a monumental failure on the part of the Honourable Minister of Justice and Attorney-General of the Federation, Mr. Abubakar Malami SAN, for the President to be allowed to commit a gaffe on such matter of national and international concern. Lastly, the statement that he (Buhari) will continue to be fair in his federal appointments is appropriate on the one hand and inappropriate on the other. It is appropriate in the sense that the right to make federal appointments resides with the President with the approval of the Senate (in most cases). On the other hand, PDP's chieftains in Delta state, Sunny Onuesoke, claims that it is inappropriate in the sense that the statement was made by a man who has vindicated those who accused him of tribalism, nepotism, sectionalism, and religious bigotry.

\section{Executive Condition}

Executive condition states that in order for one to successfully do things with words, what is said must tally with stipulated objectives and facts. As such, President Buhari's statement, "I will jail more looters" was properly executed when viewed from the aspect that his government has vowed to fight corruption. This fight has led to the introduction of Treasury Single Account and Whistle-Blowing policies. On the other hand, the statement on the rule of law being subject to national interest runs counter to the dictates of the Constitution, which upholds the rule of law over national interest (Asadu, 2018). In as much as Buhari in his inaugural address on 29th May 2015 said that he belonged to everybody and nobody, his actions as they concern federal appointments, made the statement, "I will continue to be fair in my federal appointment," flout the executive condition.

\section{Fulfilment Condition}

Every speech act, in line with Austin's performatives, is aimed towards performing an action. The fulfilment condition examines the level to which the speech act was successfully performed. The timeline for the fulfilling this statement is the end of Buhari's first tenure and possibly the end of his second tenure. But the timeline used in this research is towards the end of his first tenure. As at the time of writing this paper, Buhari has not 'jailed' anyone except that he banned 50 high-profile Nigerians from travelling outside the country and thirty-four out of the 50 names have been unveiled by The Nation. From the thirty-four names, The Nation revealed, included 13 former governors and seven ex-ministers. After the statement that the rule of law is subject to national interest, Buhari has not acted in line with what he said. On the contrary, five days after he made the statement, he contradicted himself by telling Angel Merkel that he (Buhari) would always uphold the rule of law governing the country. On the other hand, a key appointment Buhari has made after his speech on being fair in his appointment was to replace former Minister of Women Affairs and Social Development, Aisha Alhassan, who resigned on 30th September 2018 with Aisha Abubakar, the Minister of State for Industry and Investment as acting Minister of Women Affairs. This is in contrast with replaying Seiyefa from Bayelsa with Bichi from Kano State as DSS chief. It seems that Buhari did not tergiversate from his appointment ideology. Maybe what he meant by being 'fair' in his federal appointments was to cede appointing people from other parts of Nigeria aside the north into federal positions. However, since there have not been further appointments made by the President after the statement, the fulfilment of the speech act cannot be ascertained.

\section{Perlocutionary Effects}

The last level in the three-level analysis of speech acts is the perlocutionary effects. That is, the influence that the force of the locutionary and illocutionary acts has on people. The timeline of effects employed in this research is from the time the statements were made and mid-October 2018. In this regard, we will examine the reactions of Nigerians to the political discourses made by Buhari.

One of the first persons to react to Buhari's statement of jailing more thieves is the former Deputy National Publicity Secretary of the All Progressives Congress (APC), Timi Frank, who took the statement as a threat to Nigerians. Frank 
equally noted that Nigeria is a democratic state, which demands that a recognised and skilled court must find an accused guilty before sending the person to prison. Timi Frank also challenged Buhari to start his jailing spree with the members of his party (APC) who have stolen Nigeria's common wealth at all levels. He concluded that the President does not have the right to jail anybody because Nigeria is not in military rule. A former governor of Akwa Ibom State, Victor Attah, as reported by Adeniji (2018), has urged Buhari to rescue the kidnapped Christian Dapchi schoolgirl, Leah Sharibu, as he (Buhari) moves to jail more looters.

Prior to this statement made by Buhari to jail more looters, there have been commendations on the anti-corruption war by the President on the one hand and hues and cries on the other. As reported by Nwachukwu (2018), the United Nations Secretary-General, Antonio Guterres has commended Buhari for his anti-laundering efforts, which have seen funds returned. In the same vein, the French ambassador to Nigeria, Dennis Guaer remarked that Buhari is now popular with his anti-corruption war and it appears as a historical effort to fight corruption (Oyibode, 2016). Amidst these international commendations, the former Prime Minister of America (David Cameron) has referred to Nigeria as a 'fantastically corrupt' country and comments like 'shithole' and 'lifeless' have been uttered by the United States' President, Donald Trump.

From the local scene, the anti-graft war led by President Buhari has attracted a lot of reactions from Nigerians. Anele (2018) opines that "it is undeniable that in the on-going war against corruption, Muhammadu Buhari is not really eager to beam the searchlight on his loyalists, cronies and rapaciously corrupt politicians who contributed significantly to his electoral victory in 2015." He further claims that the insincere prosecution of Senate President, Bukola Saraki, by the Code of Conduct Tribunal and the suspension of Secretary to the Government of the Federation, Babachir Lawal were probably meant to mislead gullible Nigerians that anti-corruption programme is not discriminatory. The concern of Olaito (2018) is that the war against corruption must not be focused on individuals based on religious and ethnic cleansing or just to settle a score or two. Rather, the war should be fought with equity and clean hands. This implies that it appears that APC has become a strong tower where corrupt personalities run to and are saved.

The statement that the rule of law is subject to national interest also had its effects on Nigerians. Egbe (2018) reports that Wole Soyinka has criticised Buhari's statements by saying, "Here we go again! At his first coming, it was 'I intend to tamper with the Freedom of the Press' and Buhari did proceed to suit action to the words, sending two journalists Irabor and Thompson to prison as a reward for their professional integrity." The Nobel Laureate added, "The Rule of Law, however, outlasts all subverters, however seemingly powerful. If the consequence for society in defence of the Rule of Law were not so costly, any new attempt would have merely banal and boring, hardly deserving of attention. We know, historically, where it will end." Those who share the same thoughts with Soyinka are Ozekhome, SAN and Prof. Ojukwu, SAN. In reaction to Buhari's comment, Ozekhome retorted that “... without rule of law, there can be no nation state and without nation state, there can be no national interest." In the same vein, as reported by Nnochiri (2018), Prof. Ojukwu opined, "It is unfortunate that our President made that speech. If our President says that the rule of law must be subject to national interest, then it is an ominous sign that our democracy has failed." Another Senior Advocate of Nigeria, Abney Mohammed decried the statement of Buhari saying, "What is national interest that rule of law must be sacrificed for? A country without rule of law is a lawless jungle. It is the first time in our jurisprudence that I will hear a President complaining that the rule of law must give way for national interest."

Contrary to the above position, a civil society organisation, Project-2019 (P2019), rallied their support for the President by asserting the President's statement on national interest is legal and constitutional. They based their position on the premise that rule of law can only exist when security and national interest are assured in a place where there are peace and decorum.

Following the criticisms against Buhari on his statement that he will continue to be fair in his appointment, the Minister of Information and Culture, Lai Mohammed in his visit to the headquarters of Channels Television in Lagos defended that Buhari's appointments are not lopsided because those proposing equilibrium and federal character should focus on the overall appointments made by Buhari and the state of origin of those occupying governmental positions. Many Nigerians have criticised Buhari for not taking federal character into consideration during his appointments. As stipulated in Section 14 (3), public offices at the federal level should be evenly allocated in such a fashion that eschews partisan and promotes federal character. Anele (2018) bemoans the neglect of federal character by Buhari by asserting that he sees himself first as the President of the northern part of Nigeria and not as the President of the Federal Republic of Nigeria. This then implies that in practice, Buhari has shown that his statement, "I belong to everybody and I belong to nobody" should be discarded based on his latter statement, "I hope you have a copy of the election results. The constituents, for example, who gave me 97\% [of the vote] cannot, in all honesty, be treated on some issues with constituencies that gave me 5\%."

\section{CONCLUSIONS}

In this paper, we have examined how Buhari did things with words by adopting the three-level analysis of Austin's speech acts theory. Three locutionary acts of Muhammadu Buhari, which centered on his eagerness to jail more thieves, preference of national interest over rule of law and issues bordering on federal appointments were studied. The study revealed that these three locutionary acts are typical political discourses because they were uttered by a politician and they perform political functions. As these discourses were subjected to illocutionary acts analysis, that is, discovering 
what Buhari does with his words, the research discovered that many high-profile Nigerians have been jailed under Buhari's administration because of corruption-related offences. More so, the actions of the Presidency to choose the court orders it obeys, and a kind of act that should be regarded as terrorism, suggest that Buhari is yet to key into the democratic process of Nigeria. In addition, there is no connection between the statement of Buhari on being fair in his appointments and his actions. Buhari, through his lopsided appointments, has shown that he is the President of northern Nigeria as he continually flouts the federal character principle in his appointments.

Furthermore, in order to ascertain whether Buhari's speech acts have the expected force to achieve the desired effects, they were subjected to the felicity conditions of sincerity, preparatory, execution, and fulfilment. The analysis revealed that Buhari in the two locutionary acts flouted the sincerity conditions because rule of law is above national interest and that Buhari is not fair enough in his appointments, at least judging by the denotative meaning of 'fairness.' It was discovered that Buhari flouted the preparatory condition in his first locutionary act because all adjudicatory functions reside with the judiciary. In other words, the President has no power to jail anybody. On the other hand, it is surprising that a President of a democratic state who was elected through rule of law will posit that national interest is above rule of law. This unexpected statement from the President in front of legal luminaries and Senior Advocates of Nigeria violates the preparatory conditions. Buhari's statement to jail more looters when viewed from his anti-graft war was properly executed because fighting corruptions is one of the objectives of the Buhari-led administration. On the contrary, other statements were not properly executed. Due to the futuristic nature of Buhari's statements, they are yet to be fulfilled. These statements have generated a lot of reactions and responses from Nigerians. These reactions are what constitute the perlocutionary effects of Buhari's locutionary acts on Nigerians. Whereas some people criticised the President over his statements, others supported and defended him.

From the analysis, it is clear that there are communication deficits in Buhari's statements where statements run counter to the actions being performed. This seems to have made some Nigerians to lose faith in the promises and words of the President because of his ambivalence. After Atiku was declared as the presidential candidate of PDP in the 2019 general elections, Festus Keyamo, a strong supporter of Buhari on his Twitter handle welcomed Atiku to the presidential race and opined that it is a case of corruption (Atiku) and credibility (Buhari). This tweet attracted a lot of comments by many Nigerians, which x-rays Nigerian's faithlessness on Buhari. In conclusion, Buhari must reinvent himself in order to reignite the hope that made him to be elected in 2015 by fulfilling his campaign promises.

\section{REFERENCES}

[1] Adeniji, G. (2018). Rescue Leah as you jail more looters, ex-Gov Attah urges Buhari. punchng.com/rescue-leah-as-you-jailmore-looters-ex-gov-attah-urges-buhari (accessed on 15/10/2018).

[2] Adeolu, A. (2015). Buhari orders federal ministries, agencies to open treasury single account. www.vanguardngr.com (accessed on $15 / 10 / 2018)$.

[3] Agbedo, C. U. (2010). Online reading materials language in relation to society (sociolinguistics). Unpublished Advanced sociolinguistics lecture note, University of Nigeria, Nsukka.

[4] Agbedo, C. U. (2015). General linguistics: Historical and comparative perspectives. Nsukka: KUMCEE Ltd.

[5] Anele, D. (30 April 2018). The corrupt war against corruption (2). www.vanguardngr.com/2017/04/corrupt-war-corruption-2/ (accessed on 15/10/2018).

[6] Asadu, C. (21 August 2018). Fact check: Did any court say the rule of law is subject to national interest? www.thecable.ng/facy-check-buhari-correct-rule-law-subject-national-interest/amp (accessed on 15/10/2018).

[7] Austin, J. L. (1961). Philosophical papers. Oxford: Clarendon.

[8] Austin, J. L. (1962). How to do things with words. London: Clarendon Press.

[9] Chomsky, N. (1957). Syntactic structures. The Hague: Mouton.

[10] Egbe, R. (31 August 2018). Soyinka criticises Buhari on rule of law, national interest. thenationonlineeng.net/Soyinkacriticises-buhari-rule-of-law-national-interest (accessed on 15/10/2018).

[11] Ikhide, E. (15 September 2018). DSS DG appointment: Buhari's nepotism reaches its zenith. saharareporters.com/2018/09/15/dss-dg-appointment-buharis-nepotism-reaches-its-zenith-erasmus-ikhide (accessed on $15 / 10 / 2018)$.

[12] Information Nigeria (2018). See list of top politicians Buhari sent to jail. www.informationng.com/2018/06/see-list-of-toppoliticians-buhari-sent-to-jail.html (accessed on 14/10/2018).

[13] Jegede, M. (27 September 2015). Buhari and the treasury single account. Daily Trust, p. 22.

[14] Krisagbedo, E. C. (2010) Speech act analysis of former President Obasanjo's speeches on corruption. Unpublished M. A. thesis, Department of English \& Literary Studies, University of Nigeria, Nsukka.

[15] Mey, J. L. (2001). Pragmatics: An introduction. Oxford: Blackwell Publishing.

[16] Ndiribe, M. O. (2016). Speech act theory. In B. M. Mbah (ed.). Theories of linguistics. Nsukka: University of Nigeria Press Ltd, 236-252.

[17] Ndukwe, J. (5 September 2018). Between Buhari's national interest and the universal rule of law. www.naijanews.com/2018/09/05/between-buharis-national-interest-and-the-universal-rule-of-law (accessed on 15/10/2018).

[18] Nnochiri, I. (27 August 2018). National interest: SANs knock Buhari, insist on supremacy of rule of law. www.vanguardngr.com/2018/08/national-interest-sans-knock-buhari-insist-on-supremacy-of-rule-of-law (accessed on 15/10/2018).

[19] Nwachukwu, J. O. (24 May 2018). UN speaks on Buhari’s fight against corruption. dailypost.ng/2018/05/24/un-speaksbuharis-fight-corruption/ (accessed on 15/10/2018). 
[20] Olaito, Y. (2 August 2018). Why Buhari's anti-corruption war is failing. www.thecable.ng/buharis-anti-corruption-failing (accessed on 15/10/2018).

[21] Olaniyan, K. (13 June 2018). Buhari's anti-corruption fight and the rule of law. saharareporters.com/2018/06/13/buhari's-anticorruption-fight-and-rule-of-law-kolawole-olaniyan (accessed on 15/10/2018).

[22] Oyibode, A. (2016). Corruption war: Has Buhari made an impact in Nigeria? www.naija.ng/908342-corruption-war-presidentbuhari-made-impact-nigeria.html\#908342 (accessed on 13/10/2018).

[23] Project-2019 (P2019). Reaction to Buhari's statement on national interest and the rule of law. www.vanguard.ngr.com/2018/08/buharis-elevation-of-national-interest-above-rule-of-law-legal-constitutional/ (accessed on $15 / 10 / 2018)$

[24] Searle, J. (1969). Speech acts: An essay in the philosophy of language. London: Cambridge University Press.

[25] van Dijk, T. A. (1997). What is political discourse analysis? In J. Blommaert \& C. Bulcaen (eds.), Political linguistics. Amsterdam: Benjamins, 11-52.

[26] Wardhaugh, R. (2006). An introduction to sociolinguistics (5th ed.). Oxford: Blackwell Publishers.

[27] Wardhaugh, R. (2010). An introduction to sociolinguistics (6th ed.). West Sussex: Wiley-Blackwell.

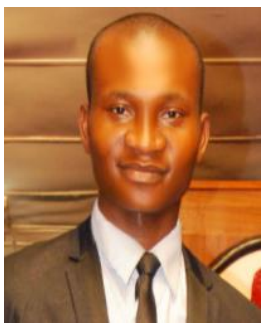

Sopuruchi C. Aboh was born in Aba, Abia State on 20th November. He had his Bachelor of Arts Degree and Master of Arts Degree in Linguistics at the University of Nigeria, Nsukka. Sopuruchi specialises in sociolinguistics and pragmatics.

He has published some articles including: "The ideology of post-truth in Nigerian cities: A discourse historical analysis", Journal of Linguistic Association of Nigeria, 22(1), 64-78 and "A comparative analysis of lexical prepositions in the Ibibio and Igbo languages", Macrolinguistics, 6(9), 36-45.

Mr. Aboh is a member of Pragmatics Association of Nigeria, Nigeria Ecolinguistics Association, and Nigerian Institute of Translators and Interpreters.

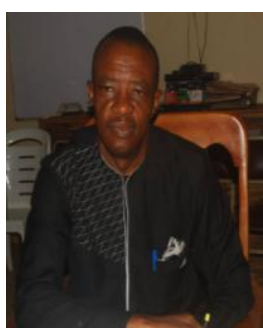

Chris Uchenna Agbedo was born in Olido Enugu-Ezike, Enugu State on 20th June. His education at the Department of Linguistics, Igbo and Other Nigerian Languages, University of Nigeria, Nsukka took place between 1982 and 1997 during which he obtained BA (Hons.), MA and PhD in 1986, 1991, and 1997 respectively. Chris specialises in sociolinguistics, pragmatics and Igbo studies.

He has written six mainline books and published over sixty book chapters and journal articles. Some of his books are: General linguistics: Historical and contemporary perspectives (Nsukka: KUMCEE-Ntaeshe Press, 2015) and Multilingualism and national development in Nigeria: Issues and challenges (Nsukka: University of Nigeria Press Ltd, 2019).

Prof. Agbedo is a Fellow of American Biographical Institute (ABI), USA and International Biographical Centre (IBC), England. Prof. Agbedo is a recipient of a number of local and international awards, notably University of Nigeria, Nsukka's Second Best graduating doctoral student (1998) and ABI's 2006 Great Minds of the 21st Century. 